\title{
SHORT TERM UNDERPRICING ANOMALY AND ITS DETERMINANT FACTORS ON SEASONED EQUITY OFFERINGS: A RESEARCH ON THE STOCKS TRADED ON THE BORSA ISTANBUL (BIST)
}

\author{
DOI: 10.17261/Pressacademia.2019.1011 \\ JBEF- V.8-ISS.1-2019(1)-p.1-16
}

Mustafa Cikrikci ${ }^{1}$, Z. Feride Olcay ${ }^{2}$, Mustafa Ozyesil ${ }^{3}$

${ }^{1}$ Istanbul Aydin University, Istanbul, Turkey. mustafacikrikci@aydin.edu.tr, ORCID: 0000-0002-2805-6079

2 Istanbul Aydin University, Istanbul, Turkey. zeynepolcay@aydin.edu.tr, ORCID: 0000-0001-5720-7350

${ }^{3}$ Istanbul Aydin University, Istanbul, Turkey.

mozyesil@aydin.edu.tr, ORCID: 0000-0002-4442-7087

Date Received: January 10, 2019 Date Accepted: March 22, 2019

To cite this document

Cikrikci, M., Olcay, Z. F., Ozyesil, M. (2019). Short term underperformance anomaly and its determinant factors on seasoned equity offerings: a research on the stocks traded on the Borsa Istanbul (BIST). Journal of Business, Economic and Finance (JBEF), V.8(1), p.1-16. Permemant link to this document: http://doi.org/10.17261/Pressacademia.2019.1011

Copyright: Published by PressAcademia and limited licenced re-use rights only.

\begin{abstract}
Purpose - The main objective of this study is to analyze the short-term price performance of the stocks issued by the 58 companies conducted 79 seasoned equity offerings (seos) during the 2010-2015 period in Borsa İstanbul and find out its determinant factors on the short-term price anomalies.

Methodology - Raw and abnormal returns were calculated then t statistics were obtained for each type of returns. All returns were compared to market average and peer groups returns. The hypotheses were tested via the comparison $t$ statistics and $t$ values. Regression analysis was used to determine what kind of determinants affect long-term price performance. To find out underperformance anomaly's determinants regression analysis was used through Panel Dynamic OLS (PDOLS) method. The analysis was also conducted based on year and sector separately.

Findings- Short-term price performance of firms that performed seos during the 2010-2015 period are the function of two dimension consist of time duration and industry because price performance of the stocks can vary depending on these factors.

Conclusion- According to the t-test results, the short-term underpricing anomaly cannot be fully confirmed in Borsa Istanbul during the analysis period. It has been confirmed statistically only in 2011 and 2015 years and in the stocks of the industrial sector. In other words, it is possible for investors to obtain higher returns than market average in the short term if they purchase shares from the seos performed in 2011 and 2015 carried out by companies in the industry sector. Determinants that considered as independent variables in study include; Stock Price, Number of Public Offerings, Company Size, Public Offering Method, Transaction Volume, Difference, Leverage Ratio, Capital Increase Rate, M / B ratio and Volatility. Based on panel regression analysis, leverage ratio change, capital increase rate and public placement have positive effect on share price performance while other variables such as $\mathrm{M} / \mathrm{B}$ ratio and private placement have a negative impact.
\end{abstract}

Keywords: Initial Public Offerings (IPO), Seasoned Equity Offerings (SEO), Price anomalies, Underpricing, Panel regression analysis. JEL Codes: C23, G10, G32

\section{INTRODUCTION}

The price anomalies oberserved in seasoned equity offerings (seos) in literature are examined separately in terms of time duration as short and long term. In most of the studies conducted in the literature, underpricing anomaly was observed in the short term while underperformance anomaly was detected in the long term. Ritter (1991) found that issuer firms' stocks provided abnormal returns to the investors that means they were underpriced for the short run while in the long term returns turned lower compared to market and peer groups performance. In this study, during the $2010-2015$ periods in Borsa İstanbul, existence of the short-term underpricing anomaly and its determinant factors will be examined. 
Underpricing term comes out when the offering price becomes lower then its fair value at the offering date. From point of this view, underpricing refers to a higher return for the investors, especially in the short run, while express decreasing issue revenue (money left on the table) for the issuer firms.

There have been many studies in the literature regarding underpricing anomaly. The most important ones include the Asymmetric Information Hypothesis, the Monopson Power of Investment Banks Hypothesis, the Waterfall Influence Hypothesis, and the Prestige of Investment Banks Hypothesis. (Ibbotson \& Ritter, 1988).

The Asymmetric Information Hypothesis focuses on the different information levels between the parties involved in the offering. If firm management realizes that fair value of the firm is lower than its market value in other words if the firm's shares are overvalued, they will prefer to go to the public for the purpose of maximizing of issue. (Myers \& Majluf, 1984).

The Monopson Power Hypothesis deals with the behavior of the investment banks in the pricing process resulting from being the sole buyer. (Logue, 1973).

The Prestige Hypothesis of Investment Banks, argues that offerings conducted by high reputable investment banks are less underpriced than offerings through lower reputable investment banks.

The Waterfall Influence Hypothesis assumes that investors focus on the information and movements of other participants in the public offering, rather than their own knowledge. This hypothesis assumes that investors take into account the actions of other actors in the investment process of the financial assets (Welch, 1992).

\section{LITERATURE REVIEW}

There are many studies in the literature regarding underpricing anomaly. One of the most important of these studies is the signaling hypothesis conducted by Welch in 1989. This hypothesis suggestes that firms regarded as small and have a low quality, may tend to have a big company image by making some earning management practices in their financials but real operational performance will be clear through seos they made in following periods. Especially the seos of the issuer firm may be perceived by the market as a negative signal related to the financial failure, therefore market generaly gives a negative respond to the the announcement of share issue. Hess and Frost (1982), confirmed the effective market hypothesis suggests that the issuance of new stocks has no impact on the share prices.

Parson and Raviv (1985), observed the underpricing anomaly and argued that this anomaly originated from the demand for issued stocks and the allocation of the stocks between the investors. Gerard and Nanda (1993), investors with insider information lead prices to get lower by selling stocks before seos which causes underpricing anomaly. Corwin (2003), found out that seos were underpriced as \%2.2 during the 1980s -1990s period and the size of underpricing gradually increased over time. Altınkılıç and Hansen (2003), calculated underpricing effect as \%3 during the 1990s. They observed increase in underpricing size compared to previous period. They concluded that this stems from increased demand of fund providers and high-risk profile of issuer firms. In addition, underpricing effect in the NASDAQ was found higher than the NYSE and AMEX.

Bowen, Chen and Cheng (2008), analyzed 4,766 seos for the 1984-2000 period and found that analyst follow-up list would reduce the size of the underpricing thanks to increased information sharing and transparency. Ruutu (2010), revealed that offerings of fully marketed stocks were being more underpriced than offerings conducted by accelerated pre-demand method by using 364 firms' data during 2000-2005 period. Also, found that capital ownership characteristics do not affect the underpricing anomaly. Lo (2011), showed existence of a negative relationship between the underpricing size and corporate transparency.

Ngo and Varela (2012), by examining 3.304 offerings during the 1989-2009, they showed that if high-quality firms have positive estimates of cash flows for future periods, then they might want to increase aggressively the offering price to reduce the degree of underpricing. Dempere (2012), examined a sample of 1,840 seos between 2003 and 2011 and found a negative relationship between offering price and underpricing level.

Goodwin (2013), investigated real estate investment trusts between 1994 and 2006 and indicated that the underpricing anomaly is a function of asymmetric information level.Jiang, Stohs and Xie (2013), found that firms make high underpricing, experience abnormal increases in stock prices and issue large amounts stocks in ipo; are tend to turn to the market earlier than the other firms. Return of the firms that issue during the first six months after the ipo was \%2.69 lower than firms go the public after longer period. Deng, Hrnjić and Ong (2014), worked on real estate investment trusts and found that investor sentiment has a positive relationship with overpricing of investors and issue possibility. He, Wang and Wei (2014), studied on 3,811 seos for the period of 1997-2012 and found that the size of the underpricing was related to the reductions in the liquidity significantly and negatively. 


\section{UNDERPRICING OF SEASONED EQUITY OFFERINGS IN TURKEY}

\subsection{Data and Sample Construction}

The data of the listed companies that conduct seos in BIST during the 2010-2015 period were used. Daily returns of the firms and Borsa Istanbul 100 National Index (BIST - 100), the capital increase announcements made by the companies, capital increase breakdown information (method, fund size obtained), book value, and other financial information were used in the analysis. Historical price information were obtained from BIST, summary information related to capital increase by years were obtained from Capital Market Board (CMB)'s weekly bulletins, announcements related to capital increase and financial statements of firms were obtained from Public Disclosure Platform (KAP). Especially, in order to compatible with the previous studies in the international literature, the following methods were taken into consideration while choosing the firms included in the sample:

Capital increases that provide cash flow into the issuer company and increase its number of the shareholders were taken into account. Capital increases through the bonus issues do not provide cash flow to the companies and capital increase made in form of private placement do not increase the number of the shareholders of the issuer companies. Therefore, capital increases which are made under any of these 2 methods were excluded from analysis. In addition, one of the seos was excluded from the analysis because it was performed as a secondary offering through the sale of existing shares that doesn't provide cash flows to the company. In final sample, 79 seos conducted by 58 firms were included in the analysis. The breakdown of seos carried out during the analysis period by years and methods is shown in table 1 and 2 respectively.

Table 1: SEOs by the Year

\begin{tabular}{cccccccc}
\hline YEARS & $\mathbf{2 0 1 0}$ & $\mathbf{2 0 1 1}$ & $\mathbf{2 0 1 2}$ & $\mathbf{2 0 1 3}$ & $\mathbf{2 0 1 4}$ & $\mathbf{2 0 1 5}$ & TOTAL \\
\hline $\begin{array}{l}\text { NUMBER of } \\
\text { SEOS }\end{array}$ & $9(\% 11)$ & $19(\% 24)$ & $15(\% 19)$ & $14(\% 18)$ & $11(\% 14)$ & $11(\% 14)$ & 79 \\
\hline
\end{tabular}

Table 2: SEOs by Year and Method

\begin{tabular}{cccccccc}
\hline YEARS & $\mathbf{2 0 1 0}$ & $\mathbf{2 0 1 1}$ & $\mathbf{2 0 1 2}$ & $\mathbf{2 0 1 3}$ & $\mathbf{2 0 1 4}$ & $\mathbf{2 0 1 5}$ & TOTAL \\
\hline $\begin{array}{c}\text { Private } \\
\text { Placement } \\
\begin{array}{c}\text { Public } \\
\text { Placement }\end{array}\end{array}$ & 3 & 5 & 1 & 4 & 3 & & $\mathbf{1 6}$ \\
\hline
\end{tabular}

Source: www.borsaistanbul.com

\subsection{Methodology}

In the analysis, short-term was regarded as the first seven days after seos in parallel with the international studies. Firstly, raw returns of stocks were calculated. Then, the adjusted returns which regarded as abnormal returns were calculated by subtracting Bist-100 returns from the raw returns. Raw Returns $(R)$ for any day $(t)$ can be calculated through the following formula:

$$
\boldsymbol{R}_{i t}=\frac{\left(\boldsymbol{P}_{i t}-\boldsymbol{P}_{i t-1}\right)}{\boldsymbol{P}_{i t-1}}
$$

$\boldsymbol{R}_{i t}$ : The return of stock $\mathrm{i}$ at time t, $\boldsymbol{P}_{\boldsymbol{i t}}$ : The closing price of the stock $\mathrm{i}$ at time $\mathrm{t}, \boldsymbol{P}_{\boldsymbol{i t}-\mathbf{1}}$ : The closing price of the stock $\mathrm{i}$ at the time t-1 (offering date).

In order to calculate the average adjusted return of stocks for any day, the returns of the Bist 100 index were calculated as the benchmark indicator.

The formula used for this purpose as follows:

$$
\boldsymbol{R}_{m t}=\frac{\left(\boldsymbol{P}_{m t}-\boldsymbol{P}_{m t-1}\right)}{\boldsymbol{P}_{m t-1}}
$$

$\boldsymbol{R}_{\boldsymbol{m} t}$ : The return of the BIST - 100 index at time t, $\boldsymbol{P}_{\boldsymbol{m} t}$ : The closing price of BIST - 100 index at time t,

$\boldsymbol{P}_{\boldsymbol{m} t-1}$ : The closing price of the BIST - 100 index at time t-1. 
In this study when calculating abnormal returns we assumed that investors are not affected by short-term market volatility and they hold the shares for a certain period. In other words, we carried out analysis under the assumption suggests that investors follow buy and hold investment strategy. The original return of the each stock called abnormal return (AR) in the literature can be calculated by subtracting the market returns calculated in Eq. (2) from the raw returns obtained in Eq. (1). Asquith and Mullins (1986), calculates AR value through the following formula:

$$
A R_{i t}=R_{i t}-R_{m t}
$$

$\boldsymbol{A R}_{\boldsymbol{i t}}$ : Abnormal return of stock i for at time $\mathrm{t}, \boldsymbol{R}_{\boldsymbol{i t}}$ : The raw return of stock i at time $\mathrm{t}$ and $\boldsymbol{R}_{\boldsymbol{m} \boldsymbol{t}}$ : Market return (Bist 100 return) at time $t$.

If day $\mathrm{t}$ which is the first day of the offering is considered as 0 then the average abnormal return of $\mathrm{n}$ shares in any day after the public offering can be calculated via the following formula of Asquith and Mullins (1986):

$$
\overline{A R}_{t}=\frac{1}{N} \sum_{i=1}^{n} A R_{i t}
$$

Another issue that needs to be examined in such analyzes is the calculation of Cumulative Abnormal Return (CAR) and the $t$ statistic for this return which occur between day $t_{1}$ and day $t_{2}$ following offering. Asquith and Mullins (1986), calculates CAR value based on following formula:

$$
C A R_{t_{1}}^{t_{2}}=\sum_{t=t_{1}}^{t_{2}} A R_{t}
$$

The average CAR value for each period is calculated using the following formula:

$$
\overline{C A R}_{t}=\frac{1}{N} \sum_{i=1}^{N} C A R_{i t}
$$

The compound abnormal return can be calculated by following Wu and Kwork (2007) as follows:

$$
B H A R_{\left(T_{1}, T_{2}\right)}=\left[\prod_{t=T_{1}}^{T_{2}}\left(1+R_{i t}\right)\right]-\left[\prod_{t=T_{1}}^{T_{2}}\left(1+R_{m t}\right)\right]
$$

$\boldsymbol{R}_{i t}$ : The raw return of i stock at time $\mathrm{t}, \boldsymbol{R}_{\boldsymbol{m} t}$ : Market return (Bist 100 return) at time $t$.

The average compound abnormal return can be calculated by following Wu and Kwork (2007) as follows:

$$
\operatorname{AvgBHAR_{(T_{1},T_{2})}}=\frac{1}{N} \sum_{i=1}^{N}\left(\left[\prod_{t=T_{1}}^{T_{2}}\left(1+R_{i t}\right)\right]-\left[\prod_{t=T_{1}}^{T_{2}}\left(1+R_{m t}\right)\right]\right)
$$

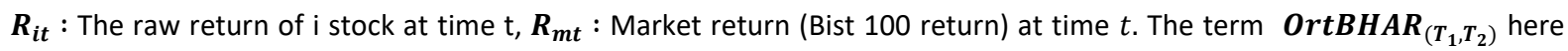
will be expressed as $\overline{\boldsymbol{B H A R}}$ in terms of ease of use at later stages of the analysis.

In order to test the statistical significance of the average abnormal, cumulative abnormal and compound abnormal returns respectively, $t$ statistics were calculated by using standard deviations. Then by comparing the $t$ statistics and critic values obtained from $\mathrm{t}$ table following hypotheses were tested:

$H_{0}: \overline{\boldsymbol{A R}}_{\boldsymbol{t}}, \overline{\boldsymbol{C A R}}_{\boldsymbol{t}}, \overline{\boldsymbol{B H A R}}_{\boldsymbol{t}} \leq \mathbf{0}$ Underpricing anomaly can be rejected,

$H_{1}: \overline{\boldsymbol{A R}}_{t}, \overline{\boldsymbol{C A R}}_{\boldsymbol{t}}, \overline{\boldsymbol{B H A R}}_{\boldsymbol{t}}>\mathbf{0}$ Underpricing anomaly can not be rejected.

Hypotheses were tested for each type of returns seperately. The t-statistics required to test these hypotheses are calculated using the following formula: (The t-statistics calculated for each type of returns but here it is shown for the AR variable)

$$
t_{i s t .}=\frac{\overline{A R}_{t}}{\bar{\sigma}\left(A R_{t}\right)}
$$

Here $\bar{\sigma}\left(A R_{t}\right)$ is the cross-sectional standard deviation at day t, calculated using the following formula:

$$
\bar{\sigma}\left(A R_{t}\right)=\left[\frac{\sum_{i=1}^{n}\left(A R_{i t}-\overline{A R}_{t}\right)^{2}}{n}\right]^{1 / 2}
$$

\section{RESULTS}

\subsection{Test Results Related to Short-Term Price Performance}

In this part of the study, analyzes were performed via the Excel 2013 and SPSS 22 program. Short-term price performances of stocks were calculated for the first 7 days following the offering. Table 3 shows price performance of stocks for the first seven days as follows: 
Table 3: Short - Term Price Performances of Stocks

\begin{tabular}{l|ccccccccc}
\hline \hline Period & $\mathbf{n}$ & $\bar{R}$ & t- ist. & $\overline{A R}$ & t- ist. & $\overline{C A R}$ & t- ist. & $\overline{B H A R}$ & t- ist. \\
\hline 1st day & 79 & 0,10 & 0,14 & $-0,03$ & $-0,04$ & $-0,03$ & $-0,04$ & $-0,03$ & $-0,04$ \\
2nd day & 79 & 0,29 & 0,55 & 0,19 & 0,37 & 0,17 & 0,17 & 0,28 & 0,26 \\
3rd day & 79 & 0,03 & 0,06 & 0,18 & 0,33 & 0,35 & 0,26 & 0,70 & 0,44 \\
4th day & 79 & 0,07 & 0,12 & $-0,13$ & $-0,20$ & 0,22 & 0,12 & 1,04 & 0,46 \\
5th day & 79 & 0,44 & 0,91 & 0,55 & 1,07 & 0,77 & 0,36 & 2,08 & 0,72 \\
6th day & 79 & 0,51 & 1,02 & 0,49 & 0,99 & 1,26 & 0,58 & 2,63 & 0,82 \\
7th day & 79 & $0,69 *$ & 1,44 & $0,77 *$ & 1,62 & 2,02 & 0,80 & 4,21 & 1,03 \\
\hline
\end{tabular}

Note: $\mathrm{n}$ represents the number of observations. Like Tarı's study (2012, pp.500), critical values for the t-test were taken as 1,282, 1,645, 2,326 and for the significance levels of $\% 10, \% 5$ and $\% 1$ respectively.

Stock returns for the analzyed period were observed as positive in the first seven-day, but statistically insignificant in the first six days. On the seventh day, there is a positive return at the level of $10 \%$ significance. Similarly, the average abnormal returns were statistically insignificant in the first six days, but a positive and statistically significant return was seen on the seventh day. Average cumulative abnormal returns were negative on the first day and positive on the following days, but these values were not statistically significant. In this case, the HO hypothesis can not be rejected for the first six days and it can be decided that the underpricing case is not valid for the stocks re-offered to the public during the 2010-2015 period. However, in accordance with the basic assumption of this study, the investors would follow buy and hold investment strategy. Therefore, they purchased these stocks in the public offering and hold them during the seven days. Under this assumption, as of seventh day they could get raw return as $0.69 \%$ and could get adjusted return as $0.77 \%$ and these values were also statistically significant. As a result, based on statistically significiant and positive values, the HO hypothesis can be rejected according to the analysis made for the 7th day and it can be claimed that the underpricing anomaly is valid for these stocks included in the sample.

The first seven-day price performances of stocks re-offered to the public by years were calculated and the findings are presented in Table 4 as follows:

Table 4: The First Seven-Day Price Performances of Stocks Re-offered to the Public by Years

\begin{tabular}{|c|c|c|c|c|c|c|c|c|c|c|}
\hline & Period & $\mathbf{N}$ & $\bar{R}$ & t- ist. & $\overline{A R}$ & t- ist. & $\overline{C A R}$ & t- ist. & $\overline{\overline{B H A R}}$ & t- ist. \\
\hline \multirow{7}{*}{ ণ্ণি } & 1st day & 9 & 0,02 & 0,02 & $-0,70$ & $-0,51$ & $-0,70$ & $-0,51$ & $-0,70$ & $-0,51$ \\
\hline & 2nd day & 9 & $-1,41 * *$ & $-2,22$ & $-1,31 * *$ & $-1,95$ & $-2,00 * *$ & $-1,83$ & $-2,05^{* *}$ & $-1,91$ \\
\hline & 3rd day & 9 & $-1,71 * * *$ & $-2,69$ & $-1,42 * *$ & $-2,04$ & $-3,42 * * *$ & $-3,04$ & $-3,43 * * *$ & $-3,09$ \\
\hline & 4th day & 9 & $-1,40 * *$ & $-1,86$ & $-1,49 *$ & $-1,62$ & $-4,91 * * *$ & $-3,43$ & $-4,89 * * *$ & $-3,49$ \\
\hline & 5th day & 9 & $-0,46$ & $-0,67$ & $-0,95^{*}$ & $-1,52$ & $-5,85 * * *$ & $-3,94$ & $-5,83 * * *$ & $-4,02$ \\
\hline & 6th day & 9 & 0,98 & 0,91 & 0,73 & 0,77 & $-5,12 * * *$ & $-3,57$ & $-5,17 * * *$ & $-3,71$ \\
\hline & 7th day & 9 & 1,63 & 1,24 & 1,18 & 1,00 & $-3,94 * *$ & $-1,88$ & $-4,01 * *$ & $-1,94$ \\
\hline \multirow{7}{*}{ ন্ } & 1st day & 19 & 1,16 & 0,89 & 0,94 & 0,72 & 0,94 & 0,72 & 0,94 & 0,72 \\
\hline & 2nd day & 19 & $-0,13$ & $-0,10$ & $-0,47$ & $-0,34$ & 0,47 & 0,21 & 0,66 & 0,26 \\
\hline & 3rd day & 19 & 0,51 & 0,35 & 0,61 & 0,40 & 1,08 & 0,30 & 1,80 & 0,42 \\
\hline & 4th day & 19 & 0,85 & 0,64 & 0,82 & 0,60 & 1,91 & 0,39 & 3,56 & 0,56 \\
\hline & 5th day & 19 & 1,13 & 1,24 & $1,34^{*}$ & 1,32 & 3,25 & 0,59 & 5,60 & 0,74 \\
\hline & 6th day & 19 & $-0,58$ & $-0,42$ & $-0,61$ & $-0,45$ & 2,63 & 0,58 & 3,68 & 0,65 \\
\hline & 7th day & 19 & 1,43 & 1,03 & $2,01^{*}$ & 1,49 & 4,64 & 0,82 & 6,89 & 0,88 \\
\hline \multirow{4}{*}{ స్ } & 1st day & 15 & $-1,82^{*}$ & $-1,51$ & $-2,50 * *$ & $-2,18$ & $-2,50 * *$ & $-2,18$ & $-2,50 * *$ & $-2,18$ \\
\hline & 2nd day & $\begin{array}{l}1 \\
5\end{array}$ & 0,18 & 0,18 & $-0,16$ & $-0,19$ & $-2,66^{*}$ & $-1,40$ & $-2,54^{*}$ & $-1,33$ \\
\hline & 3rd day & $\begin{array}{l}1 \\
5\end{array}$ & 0,63 & 0,59 & 0,62 & 0,54 & $-2,04$ & $-0,85$ & $-1,91$ & $-0,78$ \\
\hline & 4th day & $\begin{array}{l}1 \\
5\end{array}$ & $-1,73^{*}$ & $-1,41$ & $-1,75^{*}$ & $-1,28$ & $-3,79 * *$ & $-2,02$ & $-3,91 * *$ & $-2,12$ \\
\hline
\end{tabular}




\begin{tabular}{|c|c|c|c|c|c|c|c|c|c|c|}
\hline & 5th day & $\begin{array}{l}1 \\
5\end{array}$ & $-0,49$ & $-0,66$ & $-0,40$ & $-0,55$ & $-4,19 * * *$ & $-2,35$ & $-4,31 * * *$ & $-2,45$ \\
\hline & 6th day & $\begin{array}{l}1 \\
5\end{array}$ & 0,17 & 0,24 & 0,19 & 0,30 & $-3,99 * *$ & $-2,21$ & $-4,16 * * *$ & $-2,35$ \\
\hline & 7th day & $\begin{array}{l}1 \\
5\end{array}$ & $-0,74^{*}$ & $-1,48$ & $-1,10 * *$ & $-1,95$ & $-5,09 * * *$ & $-2,66$ & $-5,25 * * *$ & $-2,85$ \\
\hline \multirow{7}{*}{$\underset{\sim}{\stackrel{m}{8}}$} & 1st day & 14 & $-1,48$ & $-1,22$ & $-0,96$ & $-0,84$ & $-0,96$ & $-0,84$ & $-0,96$ & $-0,84$ \\
\hline & 2nd day & $\begin{array}{l}1 \\
4\end{array}$ & 0,71 & 1,18 & $1,26 * *$ & 2,00 & 0,31 & 0,28 & 0,27 & 0,25 \\
\hline & 3rd day & $\begin{array}{l}1 \\
4\end{array}$ & $-2,43 * * *$ & $-2,49$ & $-1,31 * *$ & $-2,06$ & $-1,00$ & $-0,76$ & $-1,05$ & $-0,82$ \\
\hline & 4th day & $\begin{array}{l}1 \\
4\end{array}$ & $1,22^{*}$ & 1,60 & 0,41 & 0,64 & $-0,59$ & $-0,35$ & $-0,59$ & $-0,37$ \\
\hline & 5th day & $\begin{array}{l}1 \\
4\end{array}$ & 0,00 & 0,00 & 0,44 & 0,52 & $-0,15$ & $-0,08$ & $-0,11$ & $-0,06$ \\
\hline & 6th day & $\begin{array}{l}1 \\
4\end{array}$ & 0,33 & 0,39 & 0,49 & 0,58 & 0,34 & 0,17 & 0,34 & 0,17 \\
\hline & 7th day & $\begin{array}{l}1 \\
4\end{array}$ & $-0,29$ & $-0,43$ & $-0,52$ & $-0,87$ & $-0,18$ & $-0,08$ & $-0,15$ & $-0,06$ \\
\hline \multirow{7}{*}{$\underset{\sim}{\mathbb{D}}$} & 1st day & 11 & $-0,79$ & $-0,35$ & $-0,51$ & $-0,22$ & $-0,51$ & $-0,22$ & $-0,51$ & $-0,22$ \\
\hline & 2nd day & $\begin{array}{l}1 \\
1\end{array}$ & 0,30 & 0,17 & 0,26 & 0,15 & $-0,25$ & $-0,08$ & $-0,22$ & $-0,08$ \\
\hline & 3rd day & $\begin{array}{l}1 \\
1\end{array}$ & 0,20 & 0,20 & 0,04 & 0,04 & $-0,21$ & $-0,09$ & $-0,33$ & $-0,13$ \\
\hline & 4th day & $\begin{array}{l}1 \\
1\end{array}$ & $-0,63$ & $-0,28$ & $-0,12$ & $-0,05$ & $-0,33$ & $-0,07$ & 0,08 & 0,02 \\
\hline & 5th day & $\begin{array}{l}1 \\
1\end{array}$ & $-0,33$ & $-0,26$ & $-0,52$ & $-0,37$ & $-0,85$ & $-0,17$ & $-0,34$ & $-0,07$ \\
\hline & 6th day & $\begin{array}{l}1 \\
1\end{array}$ & 0,58 & 0,72 & 0,48 & 0,54 & $-0,37$ & $-0,07$ & 0,07 & 0,02 \\
\hline & 7th day & $\begin{array}{l}1 \\
1\end{array}$ & 0,52 & 0,70 & 0,59 & 0,98 & 0,22 & 0,04 & 0,82 & 0,16 \\
\hline \multirow{7}{*}{$\stackrel{\text { ñ }}{\stackrel{N}{N}}$} & 1st day & 11 & $3,84^{*}$ & 1,38 & $3,88^{*}$ & 1,44 & $3,88^{*}$ & 1,44 & $3,88^{*}$ & 1,44 \\
\hline & 2nd day & $\begin{array}{l}1 \\
1\end{array}$ & 2,05 & 1,05 & 1,62 & 0,87 & $5,50 *$ & 1,35 & $5,86^{*}$ & 1,33 \\
\hline & 3rd day & $\begin{array}{l}1 \\
1\end{array}$ & $2,79 *$ & 1,48 & 2,20 & 1,05 & $7,70^{*}$ & 1,29 & 8,98 & 1,25 \\
\hline & 4th day & $\begin{array}{l}1 \\
1\end{array}$ & 1,63 & 0,70 & 0,84 & 0,32 & 8,53 & 1,05 & 11,34 & 1,05 \\
\hline & 5th day & $\begin{array}{l}1 \\
1\end{array}$ & 2,61 & 1,14 & 2,93 & 1,18 & 11,47 & 1,15 & 16,35 & 1,10 \\
\hline & 6th day & $\begin{array}{l}1 \\
1\end{array}$ & $2,63^{*}$ & 1,33 & $2,58^{*}$ & 1,35 & 14,05 & 1,21 & 21,94 & 1,12 \\
\hline & 7th day & $\begin{array}{l}1 \\
1\end{array}$ & 2,02 & 1,11 & $2,64^{*}$ & 1,50 & 16,69 & 1,26 & 28,09 & 1,13 \\
\hline
\end{tabular}

Note: $\mathrm{n}$ represents the number of observations. Like Tari's study (2012, pp.500), critical values for the t-test were taken as 1,282, 1,645 and 2,326 for the significance levels of $\% 10, \% 5$ and $\% 1$ respectively.

According to findings related to 2010, we find that the raw returns for the first, sixth and seventh days are positive but statistically insignificant. Abnormal returns are negative during the first five days and except for the first day they are statistically significant. However, on the sixth and seventh days abnormal returns were observed as positive but statistically insignificant. Average cumulative abnormal returns and average compound returns were negative for the first seven days and they were statistically significant except for the first day. Based on these findings, HO hypotheses cannot be rejected and it is decided that the underpricing anomaly for the stocks offered to the public again in 2010 is not valid. Morever, by looking at the negative and statistically significant values, it is available to say that overvaluation anomaly is valid for these stocks. The investors who bought these stocks on the day of the public offering and hold them during the seven days would suffer an average loss of $4 \%$. 
When analyzed figures for 2011, it shows that returns were positive and statistically insignificant on the first day and the other days were fluctuating. Average abnormal returns, on the fifth and seventh day are positive and statistically significant values. Looking at the average abnormal returns, the HO hypothesis is rejected at a significance level of $10 \%$ and it can be decided that the underpricing anomaly is valid for the stocks of firms that are re-offered to the public in 2011. Given cumulative abnormal returns and compound abnormal returns, it is not possible to mention about underpricing because it is statistically insignificant although they are positive during the first seven days. It is obvisously seen that investors who bought these stocks on the first day in the offering and hold them for seven days earned $4.64 \%$ more than the market, but this value can not be fully confirmed as a statistically. As a result, the existence of underpricing anomaly for seos conducted in 2011 has been confirmed by looking at only average abnormal returns.

The returns calculated for the 2012 were negative and statistically significant on the first day and the other days were fluctuating. As a result, the $\mathrm{HO}$ hypothesis can not be rejected and it is decided that the underpricing anomaly for the stocks of the companies that were offered to the public in 2012 is not valid. Based on negative and statistically significant values, it can be claimed that overvaluation is valid for these stocks included in the sample. Depeding on this findings on the table, it is seen that investors who bought these shares on the offering day and hold them during the seven days suffered more than an average of $5 \%$ losses.

Returns observed in 2013 are negative and statistically insignificant. Positive returns can be observed on the second-day but only the average abnormal return was statistically significant. On the third day, the average raw returns and average abnormal returns are found to be negative and statistically significant. On the 7th day, it is found that the average raw returns, the average abnormal returns, the cumulative abnormal returns and the average compound abnormal returns are negative and statistically insignificant. According to these results, the $\mathrm{HO}$ hypothesis cannot be rejected and it is stated that the underpricing anomaly is not valid in 2013.

According to the findings shown in the table for 2014, the returns followed a fluctuating course of the first seven days but these values were not statistically significant. In this case, the $\mathrm{HO}$ hypothesis cannot be rejected and it can be said that the underpricing anomaly is not valid in 2014.

In 2015, returns are positive and statistically significant during the first seven days. Especially average abnormal returns are positive on the 7th day and statistically significant. In this case, the HO hypothesis can be rejected at the level of $10 \%$ significance and it is seen that the underpricing anomaly is valid in 2015.

The price performance analysis by sectors for the first seven days following issuance were calculated and the findings are presentend in Table 5 as follows :

Table 5: First Seven-Day Price Performances of Stocks Re-Offered to the Public by Sector

\begin{tabular}{|c|c|c|c|c|c|c|c|c|c|c|}
\hline & Period & $\mathrm{n}$ & $\bar{R}$ & t- ist. & $\overline{A R}$ & t- ist. & $\overline{C A R}$ & t- ist. & $\overline{B H A R}$ & t- ist. \\
\hline \multirow{7}{*}{ 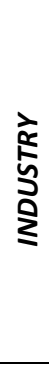 } & 1st day & 33 & $2,13^{* *}$ & 1,83 & $2,02 * *$ & 1,68 & $2,02 * *$ & 1,68 & $2,02 * *$ & 1,68 \\
\hline & 2nd day & 33 & 1,40 & 1,20 & 1,12 & 0,98 & $3,14^{* *}$ & 1,66 & $3,33^{*}$ & 1,60 \\
\hline & 3rd day & 33 & 0,25 & 0,21 & 0,21 & 0,18 & 3,35 & 1,14 & 4,18 & 1,19 \\
\hline & 4th day & 33 & 0,11 & 0,09 & 0,07 & 0,05 & 3,42 & 0,87 & 5,25 & 1,01 \\
\hline & 5th day & 33 & 1,09 & 1,10 & 0,81 & 0,75 & 4,23 & 0,91 & 7,11 & 1,07 \\
\hline & 6th day & 33 & 0,45 & 0,48 & 0,55 & 0,61 & 4,78 & 0,99 & 8,06 & 1,09 \\
\hline & 7th day & 33 & $1,41^{*}$ & 1,52 & $1,64 * *$ & 1,78 & 6,41 & 1,14 & 11,61 & 1,22 \\
\hline \multirow{6}{*}{ 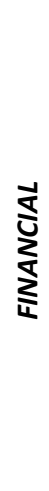 } & 1st day & 22 & $-0,81$ & $-0,58$ & $-0,89$ & $-0,71$ & $-0,89$ & $-0,71$ & $-0,89$ & $-0,71$ \\
\hline & 2nd day & $\begin{array}{l}2 \\
2\end{array}$ & $-0,39$ & $-0,85$ & $-0,42$ & $-1,10$ & $-1,31$ & $-0,99$ & $-1,30$ & $-1,00$ \\
\hline & 3rd day & $\begin{array}{l}2 \\
2\end{array}$ & $-0,09$ & $-0,11$ & 0,42 & 0,59 & $-0,89$ & $-0,62$ & $-0,91$ & $-0,65$ \\
\hline & 4th day & $\begin{array}{l}2 \\
2\end{array}$ & $1,00 * *$ & 1,65 & 0,69 & 1,26 & $-0,20$ & $-0,13$ & $-0,21$ & $-0,14$ \\
\hline & 5th day & $\begin{array}{l}2 \\
2\end{array}$ & $-0,66$ & $-1,09$ & $-0,14$ & $-0,27$ & $-0,34$ & $-0,19$ & $-0,25$ & $-0,14$ \\
\hline & 6th day & $\begin{array}{l}2 \\
2\end{array}$ & $-0,65$ & $-0,80$ & $-0,44$ & $-0,54$ & $-0,78$ & $-0,51$ & $-0,86$ & $-0,59$ \\
\hline
\end{tabular}




\begin{tabular}{|c|c|c|c|c|c|c|c|c|c|c|}
\hline & 7th day & $\begin{array}{l}2 \\
2\end{array}$ & 0,36 & 0,49 & 0,27 & 0,42 & $-0,51$ & $-0,31$ & $-0,61$ & $-0,39$ \\
\hline \multirow{7}{*}{ 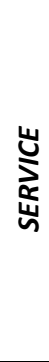 } & 1st day & 9 & $-1,34 * *$ & $-1,81$ & $-1,35^{*}$ & $-1,64$ & $-1,35^{*}$ & $-1,64$ & $-1,35^{*}$ & $-1,64$ \\
\hline & 2nd day & 9 & $-0,66$ & $-1,03$ & $-0,34$ & $-0,45$ & $-1,69$ & $-1,18$ & $-0,34$ & $-0,45$ \\
\hline & 3rd day & 9 & $-0,10$ & $-0,28$ & $-0,61$ & $-0,94$ & $-2,30$ & $-1,40$ & $-0,61$ & $-0,94$ \\
\hline & 4th day & 9 & 0,72 & 0,71 & 0,34 & 0,33 & $-1,96 *$ & $-1,64$ & 0,34 & 0,33 \\
\hline & 5th day & 9 & 0,88 & 0,69 & 1,55 & 1,04 & $-0,41$ & $-0,17$ & 1,55 & 1,04 \\
\hline & 6th day & 9 & $2,59 * *$ & 2,23 & 1,15 & 0,80 & 0,74 & 0,37 & 1,15 & 0,80 \\
\hline & 7th day & 9 & 0,38 & 0,31 & 0,60 & 0,42 & 1,34 & 0,45 & 0,60 & 0,42 \\
\hline \multirow{7}{*}{ 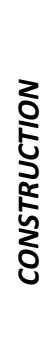 } & 1st day & 5 & $-4,16$ & $-1,15$ & $-4,36$ & $-1,18$ & $-4,36$ & $-1,18$ & $-4,36$ & $-1,18$ \\
\hline & 2nd day & 5 & $-1,97$ & $-0,89$ & $-2,03$ & $-0,86$ & $-6,39$ & $-1,09$ & $-6,00$ & $-1,09$ \\
\hline & 3rd day & 5 & 0,55 & 0,37 & 0,88 & 0,61 & $-5,51$ & $-1,18$ & $-5,44$ & $-1,18$ \\
\hline & 4th day & 5 & $-4,19$ & $-1,06$ & $-4,51$ & $-1,08$ & $-10,02$ & $-1,17$ & $-9,03$ & $-1,18$ \\
\hline & 5th day & 5 & $-0,94 * *$ & $-2,07$ & $-1,19 * *$ & $-1,73$ & $-11,21 *$ & $-1,29$ & $-10,04^{*}$ & $-1,32$ \\
\hline & 6th day & 5 & 1,43 & 0,81 & 0,95 & 0,54 & $-10,25$ & $-1,19$ & $-9,31$ & $-1,23$ \\
\hline & 7th day & 5 & $-0,38$ & $-0,48$ & $-0,92 * *$ & $-1,74$ & $-11,17$ & $-1,26$ & $-10,08^{*}$ & $-1,31$ \\
\hline \multirow{7}{*}{\begin{tabular}{l} 
ல \\
岀 \\
\multirow{2}{*}{}
\end{tabular}} & 1st day & 10 & $-1,16^{* * *}$ & $-2,51$ & $-1,53 * * *$ & $-2,36$ & $-1,53 * * *$ & $-2,36$ & $-1,53 * * *$ & $-2,36$ \\
\hline & 2nd day & $\begin{array}{l}1 \\
0\end{array}$ & 0,15 & 0,24 & 0,07 & 0,11 & $-1,45^{*}$ & $-1,50$ & $-1,44^{*}$ & $-1,49$ \\
\hline & 3rd day & $\begin{array}{l}1 \\
0\end{array}$ & $-0,58$ & $-0,98$ & $-0,07$ & $-0,12$ & $-1,53^{*}$ & $-1,56$ & $-1,50^{*}$ & $-1,57$ \\
\hline & 4th day & $\begin{array}{l}1 \\
0\end{array}$ & $-0,54$ & $-0,54$ & $-0,84$ & $-0,95$ & $-2,36^{*}$ & $-1,54$ & $-2,30 *$ & $-1,52$ \\
\hline & 5th day & $\begin{array}{l}1 \\
0\end{array}$ & 1,03 & 1,02 & 1,23 & 1,24 & $-1,13$ & $-0,57$ & $-1,08$ & $-0,54$ \\
\hline & 6th day & $\begin{array}{l}1 \\
0\end{array}$ & 0,92 & 0,96 & $1,49 * *$ & 1,74 & 0,36 & 0,20 & 0,29 & 0,16 \\
\hline & 7th day & $\begin{array}{l}1 \\
0\end{array}$ & $-0,15$ & $-0,14$ & $-0,02$ & $-0,02$ & 0,34 & 0,14 & 0,26 & 0,11 \\
\hline
\end{tabular}

Note: $\mathrm{n}$ represents the number of observations. Like Tarı's study (2012, pp.500), critical values for the t-test were taken as $1,282,1,645$ and 2,326 for the significance levels of $\% 10, \% 5$ and $\% 1$ respectively.

According to the findings represented in table, the average returns of the industrial firms are positive and statistically significant during the first seven days. In this case, HO hypothesis are rejected at the $10 \%$ significance level and it is seen that underpricing is valid for the industrial sector stocks. The average returns of the financial firms generally are found statistically insignificant. The values observed for 7 th day is not statistically significant, so the existence of underpricing is not fully confirmed. The initial average daily returns for the service firms' stocks are negative and statistically significant. Rest on this finding, it can be claimed that the HO hypothesis cannot be rejected and overvaluation can be regarded as a valid for these firms. On the following days, a fluctuating price movement was observed. The average raw returns are positive on the sixth day and statistically significant but on the seventh day, the raw returns are positive and statistically insignificant. Under the assuming that investors are following the buy and hold strategy, it can be stated that the cumulative abnormal return of the investor holds the shares from the issuance until the 7 th day is $1.34 \%$. However, the result obtained at the end of the seventh day is not confirmed as statistically. Therefore, it can be concluded that underpricing anomaly is not valid for the service sector firms. The returns of the construction sector firms were found as negative and the results were statistically significant. In this case, the HO hypothesis cannot be rejected and it can be assumed that the overvaluation anomaly is valid for these firms. The returns of energy sector companies are negative and statistically significant on the first day. This continued for the average cumulative abnormal returns and the average compound abnormal returns for the first four days after the issuance. Average abnormal returns, average cumulative abnormal returns and average compound abnormal returns at the end of the seventh day are not statistically significant. Therefore, although the cumulative abnormal returns and the cumulative compound abnormal returns are positive at the 
end of the 7th day, because the results are not statistically significant we cannot confirm that the investor can gain more than market average during the analysis period. Therefore we cannot confirm fully HO hypothesis.

\subsection{Determinants of Short-Term Price Performance of Equities}

At this stage of the analysis, regression model was performed by using AR and CAR values calculated in previous analysis as dependent variables and 10 determinant factors as independent variables.

Variables used in these analyzes are show in Table 6. as follows:

Table 6: List of Independent Variables

\begin{tabular}{|l|l|}
\hline Offering Price (LnOP) & Prices the stocks are offered to the public \\
\hline Public Offering Frequency (POF) & Frequency of the offering during the period. \\
\hline Volatility (V) & Standard deviations of stocks \\
\hline Asset Size (LnASSET) & Assets of the firms presented based on IFRS. \\
\hline Offering Method (oM) & Public \& Private placement. \\
\hline Volume (LnVol) & $\begin{array}{l}\text { Total transaction amounts come from the trading of the shares during analysis } \\
\text { period. }\end{array}$ \\
\hline Difference (DF) & Difference between obtained income and target income \\
\hline Leverage Change (LC) & Total Liabilities / Total Assets \\
\hline Capital Increase Rate (CIR) & The increase reflected as \% change by comparing to previous capital amount. \\
\hline Market to Book Value Ratio (M/B) & Market Value / Book Value \\
\hline
\end{tabular}

In order to prevent the varying variance problem, offer price, asset size and volume variables were included in the analyzes by taking the natural logarithm. AR and CAR values were used as dependent variables in this analysis. Volatility change was used as the standard deviation of the AR (V_AR) and CAR (V_CAR). The econometric models that are used in the analysis through $A R$ and CAR dependent variables are shown below. The models were set up based on one explanatory variable to test the effects of all variables seperately.

$$
\begin{aligned}
& \text { Model (1): } A R_{i t} \& C A R_{i t}=\beta_{0}+\beta_{1} L n O P_{i t}+e_{i t} \\
& \text { Model (2): } A R_{i t} \& C A R_{i t}=\beta_{0}+\beta_{1} P O F_{i t}+e_{i t} \\
& \text { Model (3): } A R_{i t} \& C A R_{i t}=\beta_{0}+\beta_{1} L n A S S E T_{i t}+e_{i t} \\
& \text { Model (4): } A R_{i t} \& C A R_{i t}=\beta_{0}+\beta_{1} K_{O M 1_{i t}}+e_{i t} \\
& \text { Model (5): } A R_{i t} \& C A R_{i t}=\beta_{0}+\beta_{1} K_{O M 2_{i t}}+e_{i t} \\
& \text { Model (6): } A R_{i t} \& C A R_{i t}=\beta_{0}+\beta_{1} L n V o l_{i t}+e_{i t} \\
& \text { Model (7): } A R_{i t} \& C A R_{i t}=\beta_{0}+\beta_{1} D F_{i t}+e_{i t} \\
& \text { Model (8): } A R_{i t} \& C A R_{i t}=\beta_{0}+\beta_{1} L C_{i t}+e_{i t} \\
& \text { Model (9): } A R_{i t} \& C A R_{i t}=\beta_{0}+\beta_{1} C I R_{i t}+e_{i t} \\
& \text { Model (10): } A R_{i t} \& C A R_{i t}=\beta_{0}+\beta_{1} M / B_{i t}+e_{i t} \\
& \text { Model (11): } A R_{i t} \& C A R_{i t}=\beta_{0}+\beta_{1} V_{-} A R_{i t}+e_{i t}
\end{aligned}
$$

Since the time dimension is enough, models are estimated by panel data analysis method.

The steps followed in the analysis are as follows:

* Panel unit root test used to determine stationarity level of the series,

* In order to see the existence of the interaction between the series in each model, panel causality test was conducted,

* Panel cointegration test was performed to determine whether the series was moving together in the long run,

* Finally according to previous analysis results panel regression analyzes were performed. 
In this context, firstly, the panel unit root test was performed and it was tested whether the series were stationary.

The stability of the series was examined by Im, Pesaran and Shin (2003) (IPS). These tests are based on the following model:

$$
\Delta Y_{i, t}=\delta_{i} Y_{i, t-1}+\sum_{j=1}^{p_{i}} \beta_{i j} \Delta Y_{i, t-j}+X_{i, t}^{\prime} \theta+\varepsilon_{i, t}
$$

$p_{i}$; represents the optimum lag length,

$X_{i, t}^{\prime}$; refers to external variables that contain any fixed effect or individual trend component.

In the panel unit root tests, it is tried to determine how the value of the series at the time $t$ is affected by the value at the time t-1. In IPS (2003) test, it is accepted that $\delta \_i$, which is a unit root parameter, may be different between the series.

IPS panel unit root test was performed in the study and the results obtained are presented in Table 7.

Table 7: Panel Unit Root Test Results

\begin{tabular}{|c|c|c|c|c|}
\hline \multirow{2}{*}{$\begin{array}{l}\text { Independent } \\
\text { Varible }\end{array}$} & \multicolumn{2}{|c|}{ Original Level Values } & \multicolumn{2}{|c|}{ First Differences of the Series } \\
\hline & Test Statistic & Prob.Value & Test Statistic & Prob.Value \\
\hline AR & $-1.62^{*}$ & 0.05 & $-10.77 * * *$ & 0.00 \\
\hline CAR & 1.33 & 0.90 & $-4.79 * * *$ & 0.00 \\
\hline LnOP & \multicolumn{4}{|c|}{$\begin{array}{l}\text { The unit root test cannot be performed because the series has the same values throughout the analysis } \\
\text { period, therefore, it is accepted that the series is stationary because it is composed of fixed values. }\end{array}$} \\
\hline POF & \multicolumn{4}{|c|}{$\begin{array}{l}\text { The unit root test cannot be performed because the series has the same values throughout the analysis } \\
\text { period, therefore, it is accepted that the series is stationary because it is composed of fixed values. }\end{array}$} \\
\hline LnASSET & \multicolumn{4}{|c|}{$\begin{array}{l}\text { The unit root test cannot be performed because the series has the same values throughout the analysis } \\
\text { period, therefore, it is accepted that the series is stationary because it is composed of fixed values. }\end{array}$} \\
\hline $\begin{array}{l}\text { Public } \\
\text { Placement }\end{array}$ & \multicolumn{4}{|c|}{$\begin{array}{l}\text { The unit root test cannot be performed. However, since the series consists of two values of } 0 \text { and } 1 \text {, it is } \\
\text { accepted stationary at an original level value. }\end{array}$} \\
\hline $\begin{array}{l}\text { Private } \\
\text { Placement }\end{array}$ & \multicolumn{4}{|c|}{$\begin{array}{l}\text { The unit root test cannot be performed. However, since the series consists of two values of } 0 \text { and } 1 \text {, it is } \\
\text { accepted stationary at an original level value. }\end{array}$} \\
\hline LnVol & 0.19 & 0.57 & $-9.96 * * *$ & 0.00 \\
\hline DF & \multicolumn{4}{|c|}{$\begin{array}{l}\text { The unit root test cannot be performed because the series has the same values throughout the analysis } \\
\text { period, therefore, it is accepted that the series is stationary because it is composed of fixed values. }\end{array}$} \\
\hline LC & \multicolumn{4}{|c|}{$\begin{array}{l}\text { The unit root test cannot be performed because the series has the same values throughout the analysi } \\
\text { period, therefore, it is accepted that the series is stationary because it is composed of fixed values. }\end{array}$} \\
\hline CIR & \multicolumn{4}{|c|}{$\begin{array}{l}\text { The unit root test cannot be performed because the series has the same values throughout the analysi } \\
\text { period, therefore, it is accepted that the series is stationary because it is composed of fixed values. }\end{array}$} \\
\hline M/B & \multicolumn{4}{|c|}{$\begin{array}{l}\text { The unit root test cannot be performed because the series has the same values throughout the analysis } \\
\text { period, therefore, it is accepted that the series is stationary because it is composed of fixed values. }\end{array}$} \\
\hline V_AR & -0.87 & 0.19 & $-8.27 * * *$ & 0.00 \\
\hline V_CAR & 3.13 & 0.99 & $-2.12 * *$ & 0.01 \\
\hline
\end{tabular}

Note: $*, * *$ and $* * *$ indicate stationary at the level of significance of $10 \%, 5 \%$ and $1 \%$, respectively. Fixed and trendy model was used for the test for the original level of the series, and the fixed model was used for the test for the first differences. The ideal lag length is determined according to the Schwarz information criterion.

According to the findings in Table 7, the AR series are stationary at a $10 \%$ significiant level, but generally, it is found that all series are not stationary in their original levels and become stationary when the first differences are taken. Therefore, it is available to infer that even in a seven-day period, the series contained significant fluctuations. In this case, the regression analyzes that is performed with the original level values of these series may contain the spurious regression problem. For this reason, it is necessary to perform the cointegration test before performing to the regression analysis.

Before performing the cointegration test, a panel causality test was conducted to measure the interaction between the series. The interaction between series included to analysis is important for the accuracy of the regression models (Göçer, 2015). For this reason, before econometric models are established, it is useful to test the causality relationships between 
the series. In this study, the existence of causality relations among the series was examined by Granger (1969) panel causality test.

This test is performed throught following equations.

$$
\begin{aligned}
& Y_{i t}=\alpha_{i}+\sum_{k=1}^{p} \gamma_{i} Y_{i, t-k} \sum_{k=1}^{p} \beta_{i} X_{i, t-k}+\varepsilon_{i, t} \\
& X_{i t}=\theta_{i}+\sum_{k=1}^{p} \delta_{i} X_{i, t-k} \sum_{k=1}^{p} \varphi_{i} Y_{i, t-k}
\end{aligned}
$$

$p_{i}$; represents the optimum lag length. Equation (24) examines the existence of a causality relation from $X$ to $Y$ and Equation (23) from $Y$ to X. Granger (1969) panel causality test was conducted and the results are presented in Table 8.

\begin{tabular}{|c|c|c|c|}
\hline Model & $H_{0}$ Hypothesis & F-statistic & Prob.Value \\
\hline Model 6 & $\operatorname{LnIH} \nrightarrow A R$ & $6.46 * *$ & 0.01 \\
\hline Model 11 & $V_{-} A R \nrightarrow A R$ & 0.00 & 0.99 \\
\hline Model 6 & $L n I H \nrightarrow C A R$ & $2.68 *$ & 0.06 \\
\hline Model 11 & $V_{-} C A R \nrightarrow C A R$ & 0.67 & 0.41 \\
\hline
\end{tabular}

Table 8: Panel Causality Test Results

Note: ${ }^{*}$ and $* *$ indicate causality relation from the first variable to second one at the level of significance of $10 \%$ and $5 \%$, respectively. The ideal lag length is determined according to the Schwarz information criterion.

According to the results represented in Table 8, we observed causality relationship between transaction volume and abnormal returns at $5 \%$ significance level while we couldn't find causality relation between volatility and abnormal returns. Panel cointegration test was applied to determine whether the non-stationary series move together in the long run. In this study, the existence of cointegration among the series was examined by the Perdroni (2004) test. Pedroni (2004) panel unit root test is based on the following equation:

$$
y_{i t}=\alpha_{i}+\delta_{i} t+\beta_{1 i} x_{1 i, t}+\beta_{2 i} x_{2 i, t}+\cdots+\beta_{M i} x_{M i, t}+\varepsilon_{i, t}
$$

Pedroni (2004) developed seven different test statistics to test the cointegration relationship between the series. In the study, Pedroni panel cointegration test (2004) was performed separately for each model and the obtained results are presented in Tables 9-12.

Table 9: Panel Cointegration Test Results for Model (6) (Dependent Variable AR)

\begin{tabular}{lllll}
\hline \hline & $\begin{array}{l}\text { Test } \\
\text { Statistic }\end{array}$ & $\begin{array}{l}\text { Prob. } \\
\text { Value }\end{array}$ & $\begin{array}{l}\text { Weighted Test } \\
\text { Statistic }\end{array}$ & $\begin{array}{l}\text { Prob. } \\
\text { Value }\end{array}$ \\
\hline Panel $\boldsymbol{v}$ & -1.40 & 0.91 & -1.77 & 0.96 \\
Panel $\rho$ & $-2.68^{* * *}$ & 0.00 & $-2.13^{* *}$ & 0.01 \\
Panel $\boldsymbol{t}$ & $-20.45^{* * *}$ & 0.00 & $-17.30^{* * *}$ & 0.00 \\
Panel $\boldsymbol{A D F}$ & $-9.03^{* * *}$ & 0.00 & $-9.30^{* * *}$ & 0.00 \\
Group $\boldsymbol{\rho}$ & 2.03 & 0.97 & - & - \\
Group $\boldsymbol{t}$ & $-22.33^{* * *}$ & 0.00 & - & - \\
Group $\boldsymbol{A D F}$ & $-10.31^{* * *}$ & 0.00 & - & - \\
\hline
\end{tabular}

Note: $* * *$ and $* *$ indicate cointegration relationship at the level of significance of $1 \%$ and $5 \%$, respectively.

According to the results shown in table 9 , there is a cointegration relationship between volume and abnormal returns at the $1 \%$ significance level. In other words, these series are moving together in the long-run, and the model predictions that are made with the original level values of these series will not contain the spurious regression problem. 
Table 10: Panel Cointegration Test Results for Model (11) (Dependent Variable AR)

\begin{tabular}{lllll}
\hline \hline & $\begin{array}{l}\text { Test } \\
\text { Statistic }\end{array}$ & $\begin{array}{l}\text { Prob. } \\
\text { Value }\end{array}$ & $\begin{array}{l}\text { Weighted Test } \\
\text { Statistic }\end{array}$ & $\begin{array}{l}\text { Prob. } \\
\text { Value }\end{array}$ \\
\hline Panel $\boldsymbol{v}$ & -0.17 & 0.57 & -1.18 & 0.88 \\
Panel $\rho$ & $-2.49 * * *$ & 0.00 & $-2.33^{* * *}$ & 0.00 \\
Panel $\boldsymbol{t}$ & $-12.89 * * *$ & 0.00 & $-15.49^{* * *}$ & 0.00 \\
Panel $\boldsymbol{A D F}$ & $-3.41^{* * *}$ & 0.00 & $-5.87^{* * *}$ & 0.00 \\
Group $\boldsymbol{\rho}$ & 2.02 & 0.97 & - & - \\
Group $\boldsymbol{t}$ & $-17.37^{* * *}$ & 0.00 & - & - \\
Group $\boldsymbol{A D F}$ & $-5.21^{* * *}$ & 0.00 & - & - \\
\hline
\end{tabular}

Note: $* * *$ and $* *$ indicate cointegration relationship at the level of significance of $1 \%$ and $5 \%$, respectively.

According to the results shown in table 10 , there is a cointegration relationship between volatility and abnormal returns at the $1 \%$ significance level. In other words, these series are moving together in the long-run and the model predictions that are made with the original level values of these series will not contain the spurious regression problem.

Table 11: Panel Cointegration Test Results for Model (6) (Dependent Variable CAR)

\begin{tabular}{lllll}
\hline \hline & $\begin{array}{l}\text { Test } \\
\text { Statistic }\end{array}$ & $\begin{array}{l}\text { Prob. } \\
\text { Value }\end{array}$ & $\begin{array}{l}\text { Weighted Test } \\
\text { Statistic }\end{array}$ & $\begin{array}{l}\text { Prob. } \\
\text { Value }\end{array}$ \\
\hline Panel $\boldsymbol{v}$ & 0.42 & 0.33 & -0.87 & 0.81 \\
Panel $\boldsymbol{\rho}$ & 1.39 & 0.91 & 1.37 & 0.91 \\
Panel $\boldsymbol{t}$ & $-6.55^{* * *}$ & 0.00 & $-4.72 * * *$ & 0.00 \\
Panel $\boldsymbol{A D F}$ & $-2.82^{* * *}$ & 0.00 & $-3.44 * * *$ & 0.00 \\
Group $\boldsymbol{\rho}$ & 5.04 & 1.00 & - & - \\
Group $\boldsymbol{t}$ & $-4.90^{* * *}$ & 0.00 & - & - \\
Group $\boldsymbol{A D F}$ & $-3.19^{* * *}$ & 0.00 & - & - \\
\hline
\end{tabular}

Note: ${ }^{* *}$ and $* *$ indicate cointegration relationship at the level of significance of $1 \%$ and $5 \%$, respectively.

According to the results shown in table 11, there is a cointegration relationship between volume and cumulative abnormal returns at the $1 \%$ significance level. In other words, these series are moving together in the long-run and the model predictions that are made with the original level values of these series will not contain the spurious regression problem.

Table 12: Panel Cointegration Test Results for Model (11) (Dependent Variable CAR)

\begin{tabular}{lllll}
\hline \hline & $\begin{array}{l}\text { Test } \\
\text { Statistic }\end{array}$ & $\begin{array}{l}\text { Prob. } \\
\text { Value }\end{array}$ & $\begin{array}{l}\text { Weighted Test } \\
\text { Statistic }\end{array}$ & $\begin{array}{l}\text { Prob. } \\
\text { Value }\end{array}$ \\
\hline Panel $\boldsymbol{v}$ & 0.96 & 0.16 & -1.10 & 0.86 \\
Panel $\boldsymbol{\rho}$ & 0.71 & 0.76 & -0.35 & 0.35 \\
Panel $\boldsymbol{t}$ & $-5.50^{* * *}$ & 0.00 & $-11.27 * * *$ & 0.00 \\
Panel $\boldsymbol{A D F}$ & $-9.33^{* * *}$ & 0.00 & $-12.78^{* * *}$ & 0.00 \\
Group $\boldsymbol{\rho}$ & 4.15 & 1.00 & - & - \\
Group $\boldsymbol{t}$ & $-12.64^{* * *}$ & 0.00 & - & - \\
Group $\boldsymbol{A D F}$ & $-29.74^{* * *}$ & 0.00 & - & - \\
\hline
\end{tabular}

Note: ${ }^{* * *}$ and $* *$ indicate cointegration relationship at the level of significance of $1 \%$ and $5 \%$, respectively.

According to the results shown in table 12 , there is a cointegration relationship between volatility and cumulative abnormal returns at the $1 \%$ significance level. In other words, these series are moving together in the long-run and the model predictions that are made with the original level values of these series will not contain the spurious regression problem. 
At this stage of the study, regression analysis was performed by using the Panel Dynamic Ordinary Least Squares (PDOLS) method, which considers cointegration relations between the series and avoids the problems by using pre and lag values in the estimating model.

The results of the models based on the AR and CAR dependent variables are presented in Table 13 and Table 14 respectively.

Table 13: First Seven Days Price Performance Analysis Results (Dependent Variable - AR)

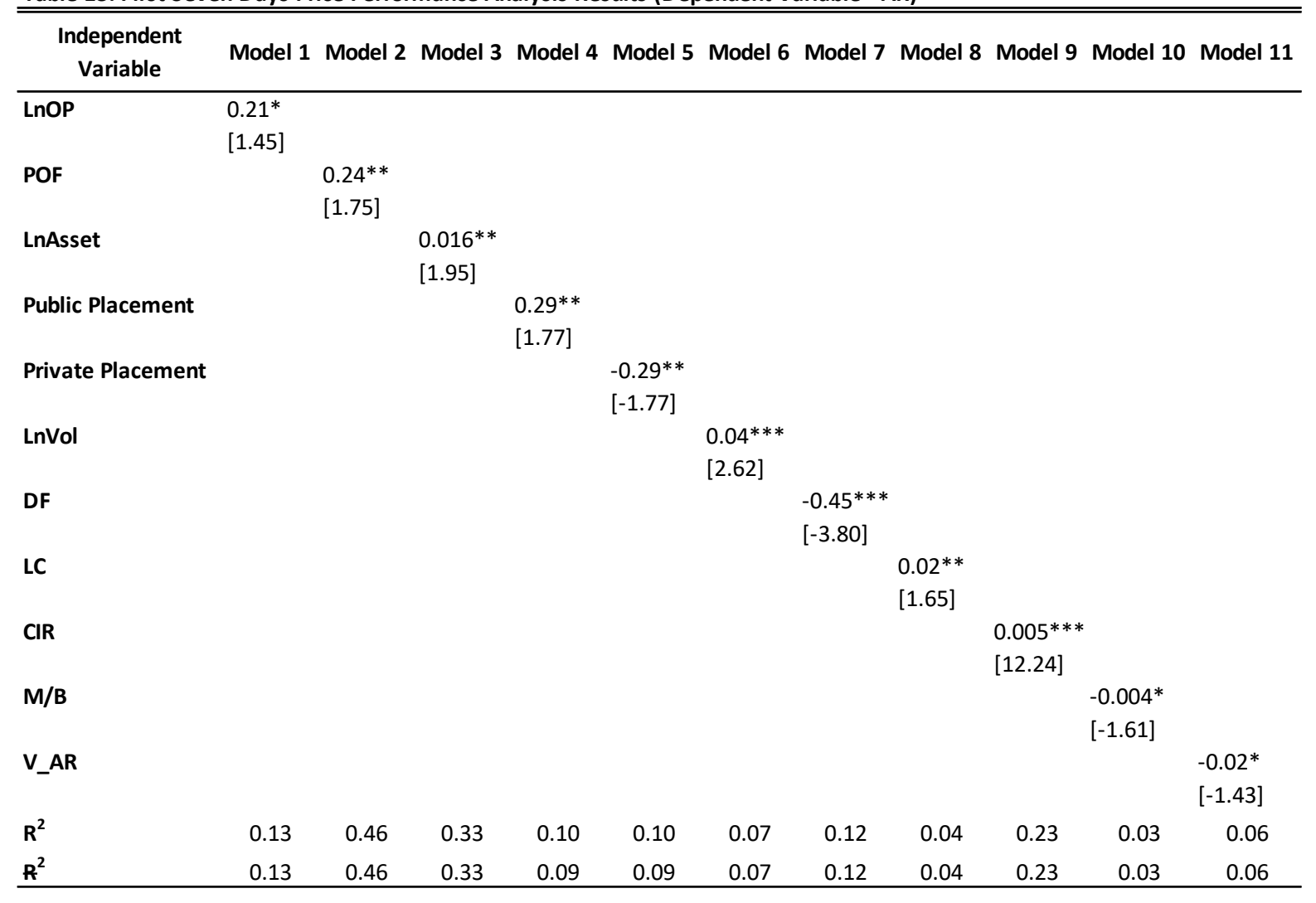

Note: ${ }^{*}, * *$ and ${ }^{* * *}$ indicate that the relevant parameters are statistically significant at $10 \%, 5 \%$ and $1 \%$ significance level, respectively. Figures in the square brackets refer to $t$ statistics while figures in the normal brackets represent probability values 
Table 14: First Seven Days Price Performance Analysis Results (Dependent Variable - CAR)

\begin{tabular}{|c|c|c|c|c|c|c|c|c|c|c|c|}
\hline $\begin{array}{l}\text { Independent } \\
\text { Variable }\end{array}$ & Model 1 & Model 2 & Model 3 & Model 4 & Model 5 & Model 6 & Model 7 & Model 8 & Model 9 & Model 10 & Model 11 \\
\hline LnOP & $\begin{array}{l}-0.02 \\
{[-1.11]}\end{array}$ & & & & & & & & & & \\
\hline POF & & $\begin{array}{l}0.16^{*} \\
{[1.57]}\end{array}$ & & & & & & & & & \\
\hline LnAsset & & & $\begin{array}{l}0.009^{*} \\
{[1.37]}\end{array}$ & & & & & & & & \\
\hline Public Placement & & & & $\begin{array}{l}0.84^{* *} \\
{[1.76]}\end{array}$ & & & & & & & \\
\hline Private Placement & & & & & $\begin{array}{l}-0.84 * * \\
{[-1.76]}\end{array}$ & & & & & & \\
\hline LnVol & & & & & & $\begin{array}{l}3.23 * * * \\
{[5.78]}\end{array}$ & & & & & \\
\hline DF & & & & & & & $\begin{array}{l}-2.19 * * * \\
{[-4.75]}\end{array}$ & & & & \\
\hline LC & & & & & & & & $\begin{array}{l}0.15^{* *} \\
{[2.23]}\end{array}$ & & & \\
\hline CIR & & & & & & & & & $\begin{array}{l}0.001^{* * *} \\
{[12.62]}\end{array}$ & & \\
\hline M/B & & & & & & & & & & $\begin{array}{l}-0.06^{* * *} \\
{[-6.27]}\end{array}$ & \\
\hline V_AR & & & & & & & & & & & $\begin{array}{l}0.02^{*} \\
{[2.38]}\end{array}$ \\
\hline$R^{2}$ & 0.19 & 0.66 & 0.11 & 0.10 & 0.10 & 0.82 & 0.27 & 0.02 & 0.40 & 0.14 & 0.31 \\
\hline$R^{2}$ & 0.19 & 0.66 & 0.11 & 0.09 & 0.09 & 0.79 & 0.27 & 0.02 & 0.40 & 0.14 & 0.31 \\
\hline
\end{tabular}

Note: $*, * *$, and $* * *$ indicate that the relevant parameters are statistically significant at $10 \%, 5 \%$ and $1 \%$ significance level, respectively. Figures in the square brackets refer to t statistics while figures in the normal brackets represent probability values

\section{THE RESULTS OF ANALYSIS PERFORMED FOR SHORT AND LONG-TERM PRICE ANOMALIES AND ITS DETERMINANTS}

As a result of the analysis, short-term underpricing anomaly could not be fully confirmed for the selected sample and analysis period in Borsa Istanbul. In the analysis conducted, it was determined that the underpricing anomaly observed only for average abnormal returns in 2011 and 2015. The average abnormal return of the investor who purchases shares from the issuance and holds them during the 7 days, gets 2,01\% in 2011 and $2.64 \%$ in 2015 higher than the market average and these findings are statistically significant. Based on this finding, the existence of an underpricing anomaly can be accepted partially in our study. In seos made in 2010 and 2012, it was determined that there was overvaluation anomaly and investors who bought shares from these offerings, obtained negative returns after the first 7 days. The underpricing anomaly for seos made in 2013 has not been fully confirmed.

When analyzed the study by sector, in the calculations made during the review period, in line with the international literature, it was determined that there was underpricing anomaly for the short-term in 34 seos conducted in the industrial sector. In all other sectors considered in the analysis except for the industrial sector, underpricing anomaly was not observed. By taking into consideration 7 days period returns in the construction sector, first and 3 days period returns in the energy sector and first day period returns in the service sector, it is possible to claim that overvaluation anomaly was experienced. It was determined that investors who bought stocks from seos in these sectors will obtain a negative return as of the 7th day. In the financial sector, underpricing is not fully confirmed statistically.

When the analysis results are evaluated in terms of price performance determinants;

Based on the findings of price performance determinant analysis for the first seven day that consider AR as dependent variable; it is determined that increase observed in the offer price, in the number of seos, in the company asset size, in the transaction volume, in leverage ratio and in capital increase ratio affect price performance of shares positively. In addition, issue method made through public placement would affect short-term price performance of shares positively. However, it 
has been found that the increase observed in the difference between obtained and targeted offering income, in the market value/book value ratio and in the volatility would affect price performance of shares negatively. By the way, issue method made through private placement also affect short-term price performance of shares negatively.

When analyzing price performance determinant analysis for the first seven day that consider CAR as dependent variable; it was determined that increase observed in the number of seos, in the company asset size, in the transaction volume in leverage ratio, capital increase ratio would affect price performance of shares positively. In addition, issue method made through public placement would affect short-term price performance of shares positively. However, it has been found that the increase observed in the difference between obtained and targeted offering income, in the market value/book value ratio and in the volatility would affect price performance of shares negatively. By the way, issue method made through private placement also affect short-term price performance of shares negatively.

The effect of the factors on the short-term stock price performance of firms that perform seos is summarized in Table 15 below.

Table 15: Short Term Price Determinants

\begin{tabular}{|c|c|c|c|c|c|}
\hline $\begin{array}{l}\text { Independent } \\
\text { Variable / Period }\end{array}$ & First Day & $\begin{array}{c}\text { The First } 3 \text { Day } \\
\text { - AR }\end{array}$ & $\begin{array}{c}\text { The First } 3 \text { Day } \\
\text { - CAR }\end{array}$ & $\begin{array}{c}\text { The First } 7 \text { Day } \\
\text { - AR }\end{array}$ & $\begin{array}{c}\text { The First } 7 \text { Day } \\
\text { - CAR }\end{array}$ \\
\hline$\overline{\mathrm{OP}}$ & + & - & - & + & $\mathrm{N} / \mathrm{A}$ \\
\hline POF & + & - & - & + & + \\
\hline V & $\mathrm{N} / \mathrm{A}$ & $\mathrm{N} / \mathrm{A}$ & $\mathrm{N} / \mathrm{A}$ & - & + \\
\hline LnAsset & - & - & - & + & + \\
\hline Public Placement & + & + & + & + & + \\
\hline Private Placement & - & - & - & - & - \\
\hline LnVol & - & - & - & + & + \\
\hline DF & + & + & + & - & - \\
\hline LC & + & + & + & + & + \\
\hline CIR & + & + & + & + & + \\
\hline M/B & - & - & - & - & - \\
\hline
\end{tabular}

\section{CONCLUSION}

As can be seen from the analysis in the study, underpricing anaomaly is not valid for all years and sectors included in the study. When looking for the other short - term periods such as the first day and the first three days, different results can be obtained for each period. In other words, the underpricing may be confirmed at any time of the short term but it cannot be fully confirmed at other time periods. In addition, if period that is considered as the short-term cover more days than 7 days, there may occur other factors that can affect the stock prices. For example, if the short-term period is defined as covers 15 days, in this stiuation, it is possible to see many of any developments that can affect the firm or its industry. Therefore, the price of the stock may be affected not only by seos but also by other factors. As a result, the short-term underpricing is actually a function of the chosen period.

Varying of the short-term stock price performance of firms that perform seos from year to year may be regarded as important in terms of the existence of the relationship between seos and general macroeconomic conjuncture. In this study, the effects of the micro factors that include firm and offerings method etc. on the abnormal returns are examined and a more detailed study can be obtained by including the macro factors in the analysis. The existence of the relationship between seos and the macroeconomic conjuncture will reveal that the opportunity window hypothesis that assumes issuer firms are looking for a good macroeconomic environment for the issue is valid for Borsa Istanbul.

The short-term underpricing anomaly was confirmed only in 2011 and 2015 years and only in the industry sector. It can be considered that this is related with underpricing seen in the initial public offerings in order to maximize the income raised by the following offerings. Especially overvaluation case seen in some sectors is a consequence of the firms' underpricing application in order to maximize issue revenue that will be conducted in later periods. This assumption will be tested with price analysis of the sample firms in the initial public offerings. It would be a reasonable decision for the investors to buy shares of industrial sector firms in order to earn a higher return than the market average in the short term. In addition, the holding period of shares and issuance years should be taken into consideration. 


\section{REFERENCES}

Altınkılıç, O., Hansen, R. S. (2003). Discounting and underpricing in seasoned equity offers. Journal of Financial Economics, 69 (2), 285 - 323.

Asquith, P., Mullins, D. W. (1986). Equity issues and offering dilution. Journal of Financial Economics, (15), 61 - 89.

Bowen, R. M., Chen, X., Cheng, Q. (2008). Analyst coverage and the cost of raising equity capital: Evidence from underpricing of seasoned equity offerings. Contemporary Accounting Research - The Canadian Academic Accounting Association, 25 (3). 641 - 946.

Corwin, S. A. (2003). The Determinants of Underpricing For Seasoned Equity Offers. Journal of Finance, 58 (5). 2249 - 2279.

Dempere, J. M. (2012). Factors That Impact Underpricing of Seasoned Equity Offerings. Review of Business, 33 (1). $65-82$.

Deng, X., Hrnjic, E., Ong, S. E. (2014). Investor sentiment and the SEO pricing process: Evidence from REITs. Journal of Real Estate Literature, 20 (2). 85-109.

Gerard, B, Nanda, V. (1993). Trading and manipulation around seasoned equity offerings. The Journal of Finance, 48 (1), $213-245$.

Goodwin, K. R. (2013). Discounting and underpricing of REIT seasoned equity offers. Journal of Real Estate Research, 35 (2), 153 - 172.

Göçer, İ. (2015). Ekonometri. İzmir: Lider Yayınları.

Granger, C. W. J. (1969). Investigating causal relations by econometric models and cross-spectral methods. Journal of Econometric Society, (37), 424-438.

He, Y., Wang, J., Wei, J. K.C. (2014). A comprehensive study of liquidity before and after SEOs and SEO underpricing. Journal of Financial Markets, (20). 61-78.

Hess, A. C., Frost, P. A. (1982). Tests for price effects of new issues on seasoned securities. The Journal of Finance, 37 (1), $11-25$.

Ibbotson, R. G., Ritter, J. R. (1988). Initial public offerings. Journal of Applied Corporate Finance, 1 (2). 37 - 45.

Im, K. S., Pesaran, M. H., Shin, Y. (2003). Testing for unit roots in heterogeneous panel. Journal of Econometrics, (115), 53-74.

Jiang, Y., Stohs, M., Xie, X. (2013). Do firms time seaosened equity offerings? Evidence from SEOs Issued Shortly after IPOs.

LO, L. Y. (2011). The impact of corporate transparency on seasoned equity offerings. International Journal of the Academic Business World, 5 (2). 77-85.

Logue, D. E. (1973). On the pricing of unseasoned equity issues: 1965-1969. Journal of Financial and Quantitative Analysis, 8 (1), 91 - 103.

Myers, S. C., Majluf, N. S. (1984). Corporate financing and investment decisions when firms have information the investors do not have. Journal of Financial Ecconomics, 13 (2). $187-221$.

Ngo, D. A., Varela, O. (2012). Earnings smoothing and the underpricing of seasoned equity offerings (SEOs). Managerial Finance, 38 (9), 833 -859 .

Parson, J. E., Raviv, A. (1985). Underpricing of seasoned issues. Journal of Financial Economics, 14 (3), 377 - 397.

Pedroni, P. (2004). Panel cointegration; asymptotic and finite sample properties of pooled time series tests with an application to the PPP hypothesis. Econometric Theory, (20), 597-625.

Ritter, J. R. (1991). The long - run performance of initial public offerings. Journal of Finance, 46 (1), 3 - 27.

Ruutu, K. (2010). Ownership structure and choice of issue method in seasoned equity offerings. Master Thesis, Helsinki School of Economics Accounting and Finance Department.

Tarı, R. (2012). Ekonometri. Kocaeli: Umuttepe Yayınları.

Welch, I. (1989). Seasoned equity offerings, imitation costs and the underpicing of initial public offerings. The Journal of Finance, 44 (2), $421-449$.

Welch, I. (1992). Sequential sales, learning, and cascades. The Journal of Finance, 47 (2). $695-732$.

Wu, C., Kwork, C. C. K. (2007). Long - run performance of global versus domestic initial public offerings. Journal of Banking \& Finance, (31). $609-627$. 